\title{
Proceeding
}

Supplementary Issue: Spring Conferences of Sports Science. 15th Convention and Workshop of the International Network of Sport and Health Science, 5-8 June 2019. University of Las Palmas de Gran Canaria, Las Palmas de Gran Canaria, Spain.

\section{Effortless swimming and movement development in childhood}

\author{
IVAN DI CARLUCCIO ${ }^{1} \square$, SIMONE ZULLI ${ }^{1}$, ANNA MARIA MARIANI'², ILARIA VISCIONE ${ }^{1}$ \\ 1 University of Salerno, Italy \\ 2University Niccolò Cusano of Rome, Italy
}

\begin{abstract}
The water skills are most important for physical and motor development. This work aim to define the whole aspects of the growth for children between 4 to 13 years old. Water skills development is different from earthly skills one, it happens in the water, a new environment with 700 time the viscosity of the air and with new skills not referable to gross motor skills. First step of swimming learning is water's fear overcoming and the learning of the basic water skills, one of the most important is the force breathing to win water's viscosity. Method is theoretical to recognize the scientific literature about the swimming learning. Results show the new procedure about teaching on heuristic learning, according to ecological approach and opposite to cognitive one. Ecological approach is very important for the first phases of the growth, focusing the educational action on fun as a mean to learn water skills and feel confident in the water. With the physical growth, prescriptive learning is progressively integrated with the ludic playing. In conclusion is significant the early introduction, the natural contact to the water to stimulate water attitudes. In the second time to suggest the traditional methods to learn the skills and master the strength to properly swim. Keywords: Swimming; Multilateral approach; Heuristic learning; Ecological approach.
\end{abstract}

\section{Cite this article as:}

Di Carluccio, I., Zulli, S., Mariani, A.M., \& Viscione, I. (2019). Effortless swimming and movement development in childhood. Journal of Human Sport and Exercise, 14(4proc), S830-S834. doi:https://doi.org/10.14198/jhse.2019.14.Proc4.45

Corresponding author. University of Salerno, Italy.

E-mail: guityivan@gmail.com

Supplementary Issue: Spring Conferences of Sports Science. 15th Convention and Workshop of the International Network of Sport and Health Science, 5-8 June 2019. University of Las Palmas de Gran Canaria, Las Palmas de Gran Canaria, Spain. JOURNAL OF HUMAN SPORT \& EXERCISE ISSN 1988-5202

(c) Faculty of Education. University of Alicante

doi:10.14198/jhse.2019.14.Proc4.45 


\section{INTRODUCTION}

The water skills are most important for physical and movement development such as the motor skills in absolute. Water skills development is different from earthly skills one, it happens in the water, a new environment with 700 times the viscosity of the air and with new skills not referable to gross motor skills(D'Elia, 2019, D'elia et al, 2019, D'isanto, 2019, D'Isanto et al, 2019, Raiola et al, 2018, Sanseviero et al, 2019). First step of swimming learning is water's fear overcoming and the learning of the basic water skills, one of the most important is the force breathing to win water's viscosity. Swimming school is the most important phase for the acquisition of the earliest water skills and to stay confident in the water. The approach is ecological dynamic and is very important to have fun in the water to keep a good concentration's level by the children. The games structure must be coherent to the acquisition of water skills and, at the same time they must be interesting for the children. The competitive swimming uses cognitive approach and prescriptive method, opposite to swimming school. The following study focuses on the educational progressions of the swimming school which is divided in different levels according to the growth stages of the children. This work aim to define the whole aspects of the growth for children between 4 to 13 years old.

\section{METHOD}

To recognize the scientific literature about the swimming learning it is utilized the theoretical argumentative approach to define the specific teaching method such as in physical education and sport by deductive, logic and rational path.

\section{RESULTS}

Results show the new procedure about teaching on heuristic learning, according to ecological approach and opposite to cognitive one. The aim is to reach and shown the active and heuristic method based on multilateralism and fun, opposite to linear method based on repetitiveness (Raiola, 2017, 2015ab, 2013, 2012ab, 2011ab, Raiola, Di Tore, 2017). Ecological approach is very important for the first phases of the growth , focusing the educational action on fun as a mean to learn water skills and feel confident in the water. With the physical growth (Ceciliani, 2019, Ceciciliani et al, 2005, D'Isanto, 2016), prescriptive learning is progressively integrated with the ludic playing. The linear method is based on mechanics repetition of the skill, with a progressively increase of training volume, the results coming fast, but they are not adaptable to children's growth in most cases. Prescriptive teaching is not indicated for the ludic expression of the movement. The active method maintains the ludic playing until 11/13 years old and focuses on technique and communication between athlete and coach (Valentini et al, 2018ab). The metabolic work is administered according to the age and technical level of the athletes, respecting the sensitive phases of the growth. Swimming technique is readapted according to the growth stages. Is important to combine sensorial circuit and other games out of the water to guarantee good corporeity and movement to the athletes. Swimming is a performance sport which requires a good development of coordination skills, in particular balance and kinaesthetic differentiation. The first part focuses on analysers perception and multilateralism.

Perception exercises to stimulate the analysers in and out of the water. Exercises to work on stabilizers muscles, coordination exercises. Exercises with educational aids like proprioceptive ball, hand paddle, finger paddle, fin. Cognitive exercises mixed to ludic exercises to learn and have fun in the water. Exercise to improve leg kick for a good propulsion in the water. Other exercises to stimulate children's curiosity, use imagination to create new exercises adapted for the children. 
As following there are the educational aids for the effortless swimming, they are in commerce by the water games factory.

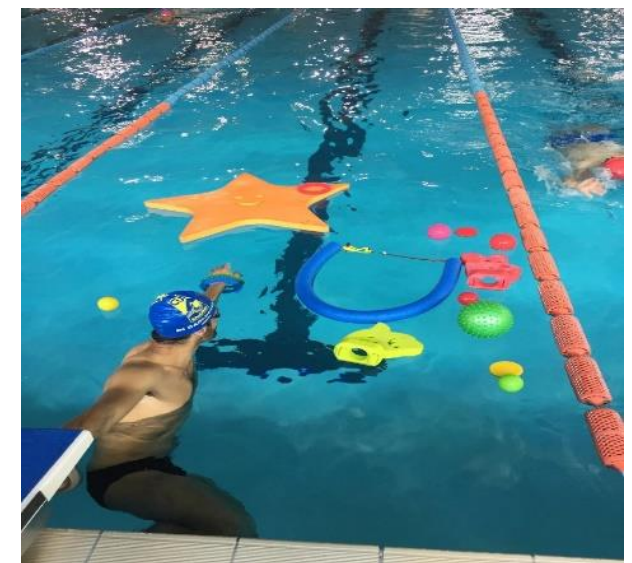

A. Hand paddle, finger paddle.

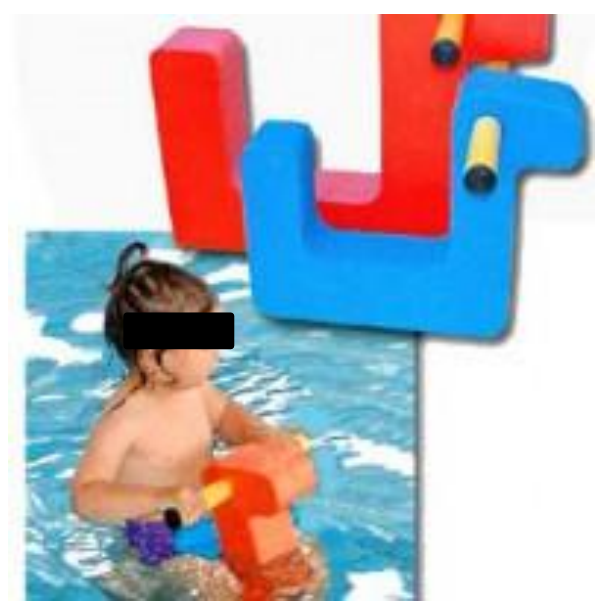

C. Little horse.

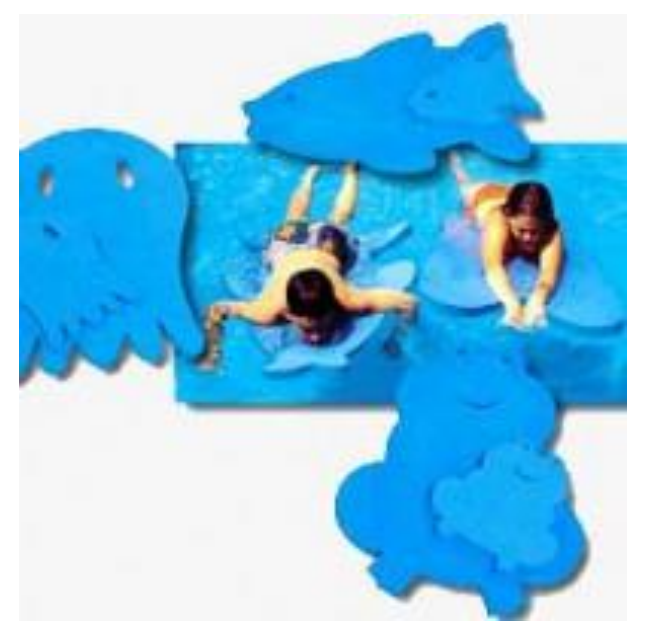

E. Animal table.

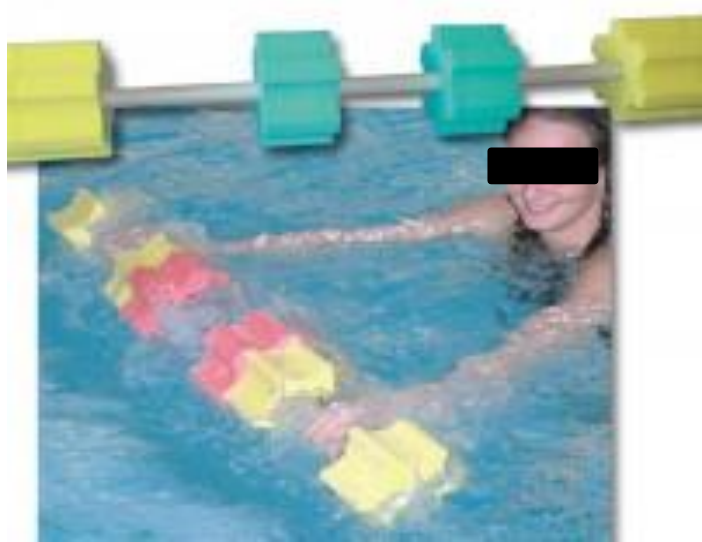

B. Outrigger.

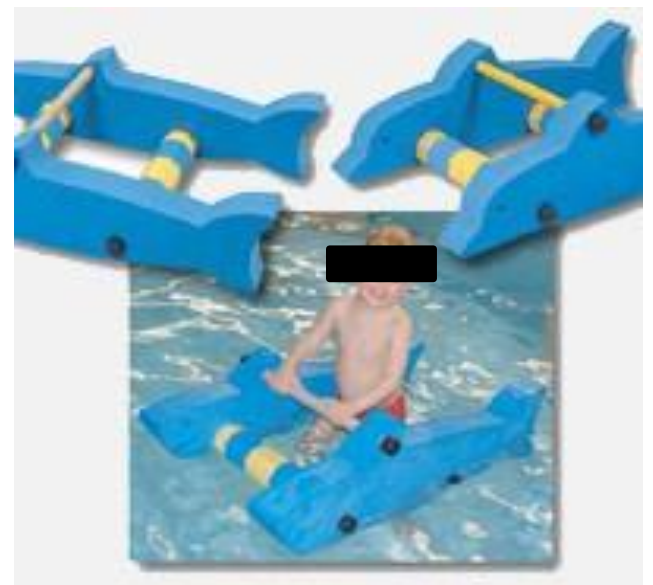

D. Maxi animal.

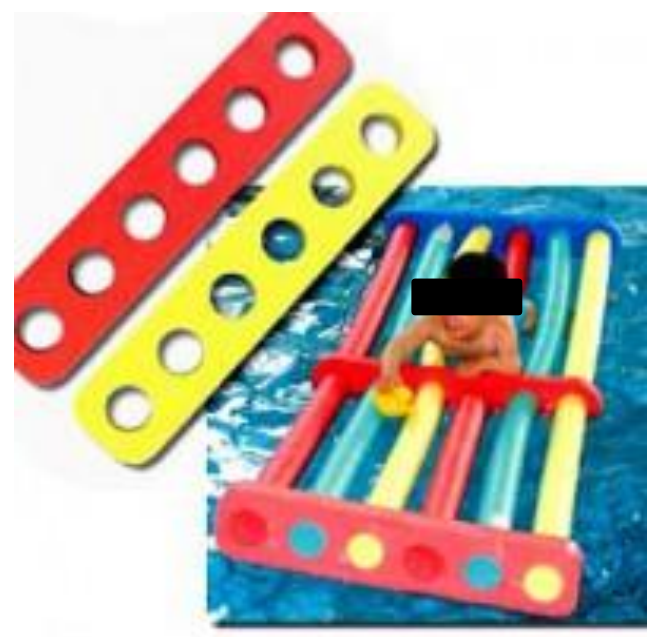

F. Couple hips 


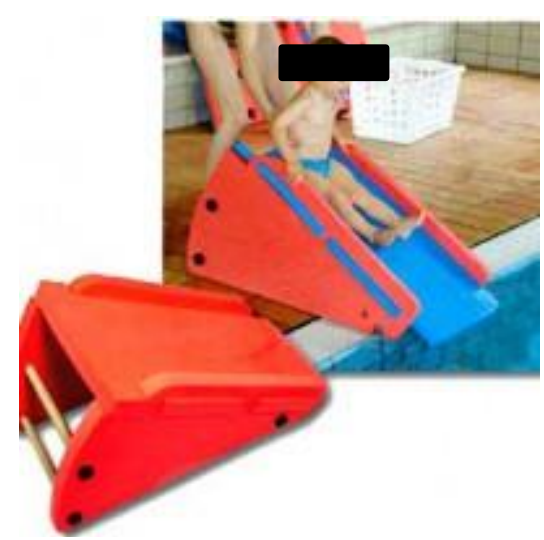

G. Maxi slide.

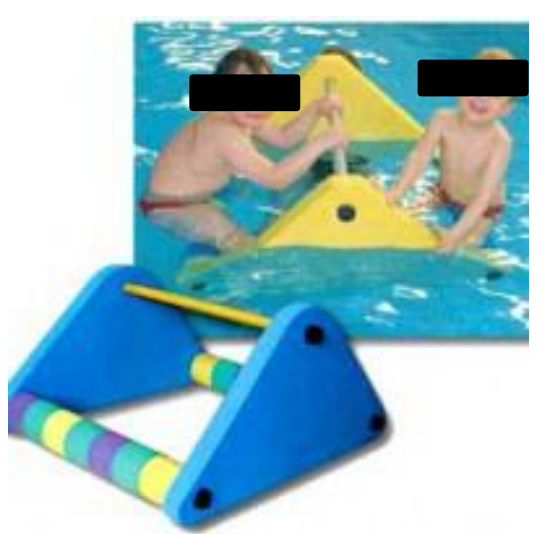

H. Aquatic rocking

Figure 1. Water tools.

\section{DISCUSSION AND CONCLUSION}

A Montessorian approach is more adaptable and effective in the most part of the cases, it help the children to stay confident in the water and have fun in it (Gaetano et al, 2015) and so, the health status is satisfied (Gaetano, 2016, Tiziana et al, 2017). It's important to adapt the environment to children's needs, to use scientific educational toys to drive the children during the movement development. The instructors are educators who respect the kids and teach them to obtain autonomy on few situations in the water. They teach them how to solve problems by themselves.

\section{REFERENCES}

Ceciliani, A. (2018) From the embodied cognition to the embodied education in the physical and sports sciences, Encyclopaideia, 22 (51), pp. 11-24.

Ceciliani, A., Di Carlo, M., Tentoni, C. (2005) Mental process learning, Medicina dello Sport, 58 (1), pp. 43-52.

D`Elia, F. (2019). The training of physical education teacher in primary school. Journal of Human Sport and Exercise, 14(1proc), S100-S104. https://doi.org/10.14198/jhse.2019.14.Proc1.12

D'Elia, F., Mazzeo, F., Raiola, G. (2018) The core curriculum in the university training of the teacher of physical education in Italy, Journal of Human Sport and Exercise, 13, pp. S413-S420. https://doi.org/10.14198//hse.2018.13.proc2.25

Gaetano, R., Domenico, T., Gaetano, A. (2015) Physical activity and its relation to body and ludic expression in childhood, Mediterranean Journal of Social Sciences, 6 (3), pp. 293-296. https://doi.org/10.5901/miss.2015.v6n3s2p293

D'isanto, T. (2019) Physical and sport education between Italian academic system and European Research Council structure panel, Journal of Human Sport and Exercise, 14, pp. S66-S76. https://doi.org/10.14198/ihse.2019.14.proc1.08

D'Isanto, T., D'Elia, F., Raiola, G., Altavilla, G. (2019) Assessment of sport performance: Theoretical aspects and practical indications, Sport Mont, 17 (1), pp. 79-82.

D'Isanto, T. (2016) Pedagogical value of the body and physical activity in childhood, Sport Science, 9, pp. 13-18.

Gaetano, A. (2016) Relationship between physical inactivity and effects on individual health status, Journal of Physical Education and Sport, 16, pp. 1069-1074. 
Raiola, G., D'elia, F., Altavilla, G. (2018) Physical activity and sports sciences between European Research Council and academic disciplines in Italy, Journal of Human Sport and Exercise, 13, pp. S283-S295. https://doi.org/10.14198/jhse.2018.13.proc2.13

Raiola, G. (2017) Motor learning and teaching method, Journal of Physical Education and Sport, 17, art. no. 236, pp. 2239-2243.

Raiola, G., Di Tore, P.A. (2017) Motor learning in sports science: Different theoretical frameworks for different teaching methods, Sport Science, 10, pp. 50-56.

Raiola, G. (2015a) Inclusion in sport dance and self perception Sport Science, 8, pp. 99-102.

Raiola, G. (2015b) Sport skills and mental health, Journal of Human Sport and Exercise, 10 (Proc1), pp. S369-S376. https://doi.org/ihse.2015.10.Proc1.27

Raiola, G. (2013) Body knowledge and motor skills, Knowledge Cultures, 1 (6), pp. 64-72.

Raiola, G. (2014) Motor control and learning skills according to cognitive and ecological dynamic approach in a vision on behaviorism, cognitive, Gestalt and phenomenology theories, Mediterranean Journal of Social Sciences, 5 (15), pp. 504-506. https://doi.org/10.5901/mjss.2014.v5n15p504

Raiola, G. (2011a) A study on Italian primary school rules: Neurophysiological and didactics aspects on physical education and sport, Journal of Physical Education and Sport, 11 (2), pp. 43-48.

Raiola, G. (2011b) Study between neurophysiological aspects and regulation documents on preschool in Italy, Journal of Physical Education and Sport, 11 (1), pp. 42-47.

Sanseviero, I., Cassese, F.P., Fonzo, E., Altavilla, G., D'elia, F. (2019) Study on the master's degree in sciences of sports evaluation and sport for disabled at the University of Salerno, Italy. Journal of $\begin{array}{lllll}\text { Human Sport and } & \text { Exercise, } 14 \text { (Proc2), pp. S239-S244. }\end{array}$ https://doi.org/10.14198//hse.2019.14.proc2.12

Tiziana, D., Antonetta, M., Gaetano, A. (2017) Health and physical activity, Sport Science, 10 (1), pp. 100-105.

Valentini, M., Riccardi, F., Raiola, G., Federici, A. (2018a) Educational research: Motor area and relational area during children's personality development, Journal of Physical Education and Sport, 18 , art. no. 327, pp. 2157-2174.

Valentini, M., Bernardini, C., Beretta, A., Raiola, G. (2018b) Movement and language development as an early childhood twin strategy: A systematic review Sport Mont, 16 (3), pp. 107-112. https://doi.org/10.26773/smj.181019

\section{(9) $(\mathbb{Q} \Theta \Theta$}

This work is licensed under a Attribution-NonCommercial-NoDerivatives 4.0 International (CC BY-NC-ND 4.0). 